\title{
A Horizontal Mesiodens in a Child Buried at Hank's Site (41RB109), a Prehistoric Plains Village Site in the Texas Panhandle
}

\author{
Cory J. Broehm*, Lisa B. Hunter, Douglas K. Boyd \\ Prewitt and Associates, Inc., Cultural Resources Services, 2105 Donley Drive, Suite 400, Austin, Texas 78758
}

\begin{abstract}
The mesiodens is the most common kind of supernumerary tooth; it is found in the midline of the maxilla. Horizontal orientation is the least common, accounting for about $6 \%$ of cases. During osteological analysis of the skeleton of a 3 to 5 year old child recovered from Hank's site (41RB109) in the northern Texas panhandle, an impacted horizontal, conical mesiodens was identified. The skeleton dates to the Plains Village period, ca. A.D. 1,200 to 1,500 , when village-based peoples practiced a mixed hunter-gatherer/horticulture
\end{abstract}

The mesiodens, the most common type of supernumerary tooth, is found in the midline of the maxilla, between and generally palatal to the central incisors. Its prevalence in the permanent dentition ranges from 0.1 to $3.6 \%$ and in the primary dentition from 0.2 to $1.9 \%$, (summarized in Sykaras, 1975), occurring more commonly in Asians (Zhu et al., 1996), including presumably Native Americans, and at least twice as often in males (e.g., Liu, 1995; Tay et al., 1984). Three orientations have been described: vertical (similar to normal teeth); inverted (crown oriented cranially); and horizontal or transverse. Vertical or inverted are both common (Asaumi et al., 2004; Liu, 1995; Rajab and Hamdan, 2002; Tay etal.,1984). The horizontal orientation is rare. Asaumi et al. (2004) found only $6 \%$ of mesiodens to be horizontal, similar to the rates of $6-8 \%$ and $5-6 \%$ for all horizontal supernumeraries reported by Rajab and Hamdan (2002) and Tay et al. (1984), respectively. The present report describes the first known incidence of an impacted horizontal conical mesiodens in a child's skeleton, recovered during on-going investigations at Hank's site (41RB109), an archeological site in the northern Texas panhandle.

\section{MATERIALS AND METHODS}

The child was interred in a flexed position in a shallow pit filled mostly with caliche cobbles. A radiocarbon assay on human bone collagen from the burial yielded a conventional radiocarbon age of $630 \pm 40$ years B.P. (Beta Analytic, Inc., Sample No. Beta-223738). The 2-sigma subsistence. This mesiodens is located in the right maxilla, just lateral to the midline of the hard palate and parallel to the intermaxillary suture. The root projects ventrally and protrudes through the external alveolar bone between the central incisors. The crown is conical. Although sometimes found in association with certain congenital disorders, the mesiodens appears to be idiopathic in this case. While possibly painful due to its proximity to the nasopalatine nerve, no sequela from the tooth growth and impaction are evident. Dental Anthroplogy 20111;24(2):55-58.

calibrated date is A.D. 1,290-1,410. A burned pithouse and other archeological remains at this site are dated to the same time, the Plains Village period, ca. A.D. 1,200 to 1,500 , during which village-based peoples practiced a mixed hunter-gatherer/horticulture subsistence (Lintz, 1986).

Standard osteological analysis was performed on the remains. The skeleton is largely complete and in a good state of preservation. Missing elements include most hand and foot bones, unfused epiphyses, the lumbar vertebrae, sternum, and patellae. All deciduous teeth are fully erupted into occlusion and many developing permanent tooth buds are visible partially or wholly in the alveoli due to damage to the maxillae and mandible. Based on development of the permanent dentition (Ubelaker, 1989) and epiphyseal fusion (Scheuer and Black, 2000), the child was 3-5 years old at the time he or she died. Due to the young age, no assessment of sex was attempted. The child's skeleton showed no evidence of illness at the time of death. The cranium exhibits positional plagiocephaly. A shallow carious lesion is present on the occlusal surface of the mandibular left first molar. A supernumerary tooth, a mesiodens, is present in the midline of the maxilla, between the deciduous central incisors.

*Correspondence to: Cory J. Broehm, PO Box 16821, Albuquerque, New Mexico, 87191 USA

e-mail: cjbroehm@gmail.com 


\section{CASE REPORT}

The mesiodens is located in the right maxilla, just lateral to the intermaxillary suture. It is perpendicular to the orientation of the natural teeth and parallel to the intermaxillary suture. The root points ventrally, protruding through the external alveolar bone at approximately the midpoint level of the central incisor roots, though it is unlikely to have protruded through the gingiva into the vestibule. Presence of the mesiodens has resulted in a lateral flaring of the roots of the deciduous central incisors (Fig. 1). This suggests the mesiodens developed from the primary dentition, as the mesiodens would have formed prior to formation of the roots of the central incisors. Mesiodens of the primary dentition are up to five times less common than those of the permanent dentition (Primosch 1981). The crown of the mesiodens points posteriorly and angles slightly superiorly. Growth of the mesiodens has led to resorption of bone in the incisive fossa of the hard palate, exposing part of its central crown (Fig. 2). This oval fenestration measures $4.28 \mathrm{~mm}$ (anteroposterior) by $2.95 \mathrm{~mm}$ (mediolateral). The incisive foramen (fossa) is also laterally widened on the affected maxilla. Similar resorption along the medial surface of the intermaxillary suture has exposed almost the entire length of the tooth, except the distal half of the crown (Fig. 3). A thin bridge of bone separates the palatal and sutural fenestrations. The mesiodens has also caused a slight depression on the intermaxillary suture surface of the left maxilla, anterior to the incisive foramen. There is no evidence of infection or inflammation associated with the mesiodens.

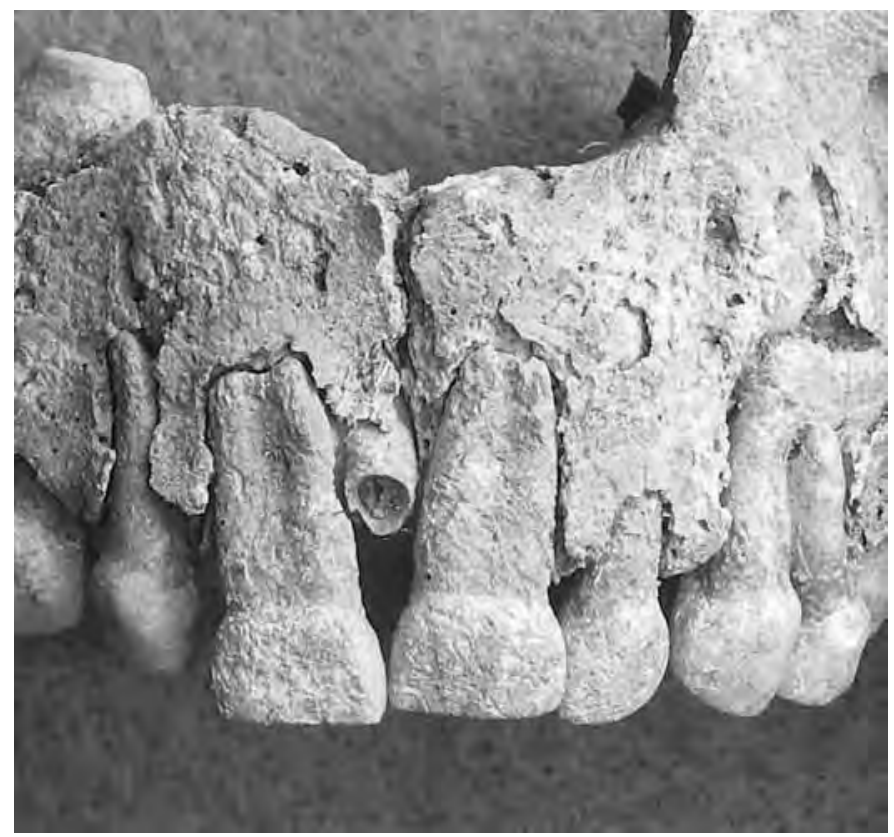

Fig. 1. Mesiodens root protruding through alveolar bone between the primary central incisors. Photograph by Jennifer McWilliams.
The mesiodens measures $11.7 \mathrm{~mm}$ in length. Its crown is conical in shape (Fig. 4) and slightly oval in cross-section at its widest, measuring $6.3 \times 5.3 \mathrm{~mm}$. The mesiodens root is incomplete (4.2 $\mathrm{mm}$ in length). Although there is some postmortem erosion at the root end, the mostly smooth, even margins indicate incomplete development rather than postmortem loss of the rest of the root. It is unclear if development had stopped, leaving an incomplete root, as often happens with a mesiodens (Primosch, 1981), or was still ongoing at the time of death.

\section{DISCUSSION}

The mesiodens is the most common type of supernumerary tooth, and horizontal mesiodens are the rarest subtype, accounting for about $6 \%$ of cases in the literature (Asaumi et al., 2004). Mesiodens most often occur singly, but may be found in higher numbers. They can be primary or permanent, and normal (eumorphic, like other teeth in the morphogenetic field) or abnormal in crown shape, the latter also having a smaller root and crown (Primosch, 1981; Russell and Folwarczna, 2003; von Arx, 1992). The three morphological types of mesiodens with abnormal crowns are conical, tuberculate, and molariform, the first shape being most common (Primosch, 1981; Rajab and Hamdan, 2002).

Research suggests a multifactorial etiology for supernumerary tooth formation (Brook et al., 2002; Sedano and Gorlin, 1969). A remnant or hyperactive dental lamina or abnormal division of a tooth bud

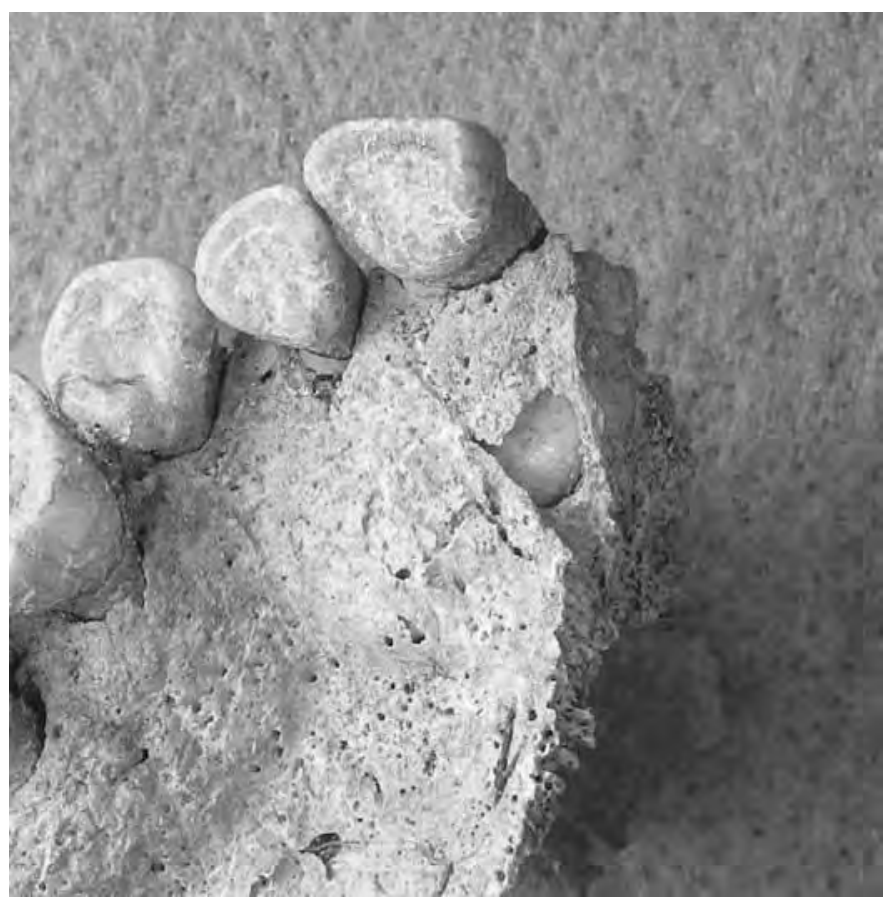

Fig. 2. Premortem fenestration of alveolus in the palate dorsal (posterior) to central incisor, exposing the mesioden's crown. Photograph by Jennifer McWilliams. 


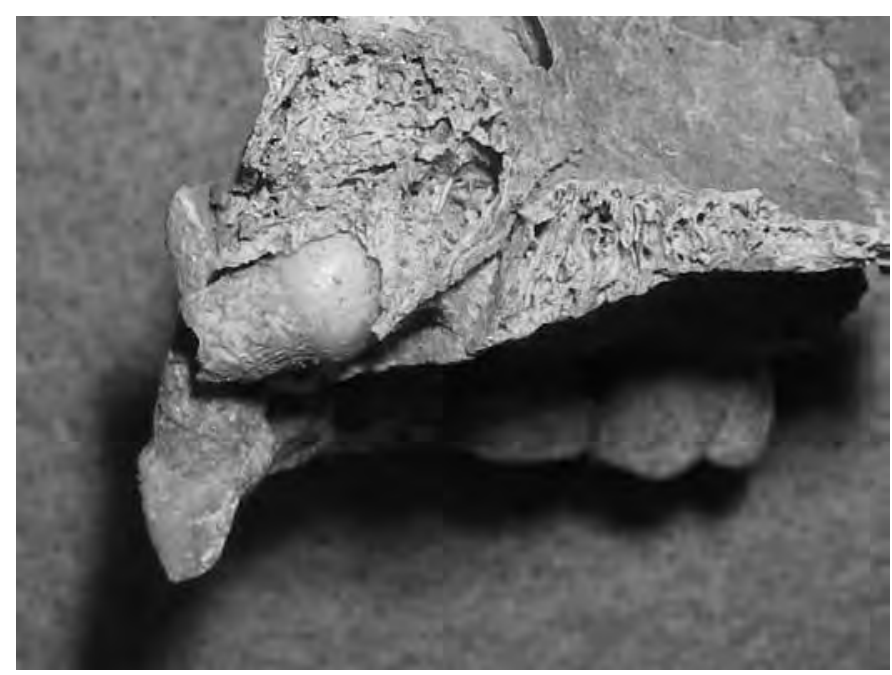

Fig. 3. View of mesiodens in intermaxillary suture of right maxilla. Ventral (anterior) is to left. Photograph by Jennifer McWilliams.

are proposed mechanisms (Buggenhout and BailleulForestier, 2008; Russell and Folwarczna, 2003). Certain disorders, particularly cleft lip and palate (Milhon and Stafne, 1941) and cleidocranial dysplasia (Jensen and Kreiborg, 1990), are also associated with supernumerary tooth formation.

Mesiodens erupt less than one-third of the time (Liu, 1995; von Arx, 1992) but are often asymptomatic. An impacted mesiodens will usually be suspected due to problems in the development of the dentition (e.g. the angulated central incisors in this case) and is then diagnosed radiographically. Common clinical sequelae include delayed or lack of eruption of permanent teeth, deviation of eruption path, rotation, retention, root dilaceration, root resorption or loss of tooth, diastema, and malocclusion (e.g., Asaumi et al., 2004; Nazif et al., 1983; Russell and Folwarczna, 2003; von Arx, 1992; Zmener, 2006). Eruption of an inverted mesiodens into the nasal cavity can also result in congestion or obstruction of the nasal passage, and development of rhinitis and, possibly, a nasal fistulae (Smith et al., 1979).

\section{CONCLUSION}

The horizontal mesiodens recorded in this child from Hank's site in the northern panhandle of Texas appears to be idiopathic and not associated with any congenital malformation. While conceivably experiencing pain from the impaction of the tooth, particularly as it impinged on the nasopalatine nerve, the child did not suffer from any obvious problems in development of the primary dentition aside from some flaring of the deciduous central incisors. Anterior mesiodens, like the one reported here, tend to create more problems with the primary or permanent dentition than

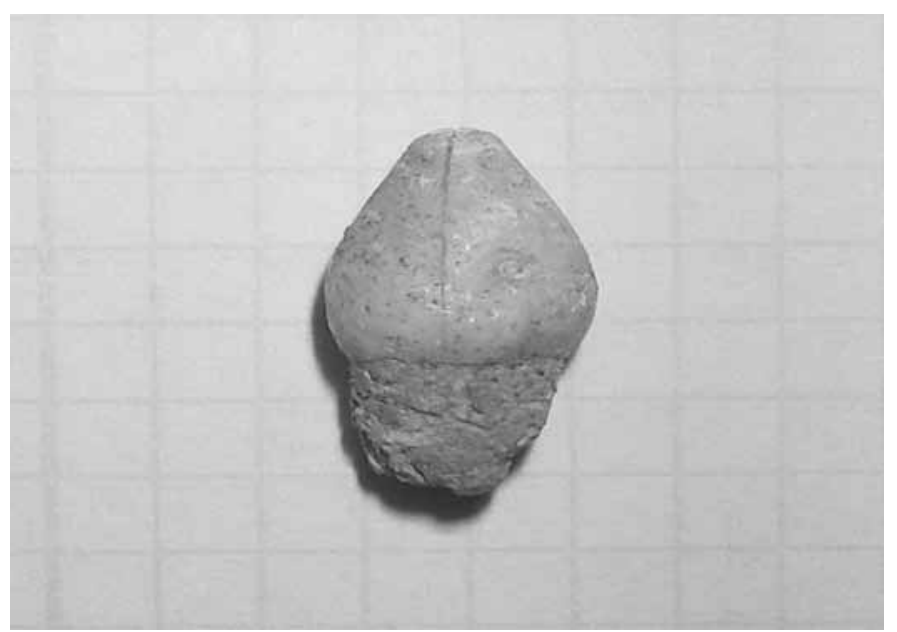

Fig. 4. Mesiodens after removal from maxilla. Each square equals 0.1 inch. Photograph by Jennifer McWilliams.

posterior (Buggenhout and Bailleul-Forestier, 2008). But a horizontal mesiodens with a crown distal to the arcade is perhaps less likely to complicate development than a horizontal mesiodens where the crown crowds the arcade, or a vertical or inverted mesiodens (e.g., Zmener, 2006). The permanent dentition, particularly the right central incisor, may have eventually exhibited misalignment.

\section{LITERATURE CITED}

Asaumi JI, Shibata Y, Yanagi Y, Hisatomi M, Matsuzaki H, Konouchi H, Kishi K. 2004. Radiographic examination of mesiodens and their associated complications. Dentomaxillofac Radiol 33:125-127.

Brook AH, Elcock C, Al-Sharood MH, McKeown HF, Khalaf K, Smith RN. 2002. Further studies of a model for the etiology of anomalies of tooth number and size in humans. Connect Tissue Res 43:289-295.

Buggenhout GV, Bailleul-Forestier I. 2008. Mesiodens. Eur J Med Genet 51:178-181.

Jensen BL, Kreiborg S. 1990. Development of the dentition in cleidocranial dysplasia. J Oral Pathol Med 19:89-93.

Lintz CR. 1986. Architecture and Community Variability within the Antelope Creek Phase of the Texas Panhandle. Studies in Oklahoma's Past, Number 14. Oklahoma Archeological Society, Norman.

Liu JF. 1995. Characteristics of premaxillary supernumerary teeth: A survey of 112 cases. ASDC J Dent Child 62:262-265.

Milhon JA, Stafne EC. 1941. Incidence of supernumerary and congenitally missing lateral incisor teeth in 81 cases of harelip and cleft palate. Am J Orthod 37:599604. 
Nazif MM, Ruffalo RC, Zullo T. 1983. Impacted supernumerary teeth: A survey of 50 cases. J Am Dent Assoc 106:201-204.

Primosch RE. 1981. Anterior supernumerary teethassessment and surgical intervention in children. Ped Dent 3:204-215.

Rajab LD, Hamdan MM. 2002. Supernumerary teeth: Review of the literature and a survey of 152 cases. Int J Paediatr Dent 12:244-254.

Russell KA, Folwarczna MA. 2003. Mesiodens-diagnosis and management of a common supernumerary tooth. J Can Dent Assoc 69:363-366.

Scheuer L, Black S. 2000. Developmental Juvenile Osteology. San Diego: Academic Press.

Sedano HO, Gorlin RJ. 1969. Familial occurrence of mesiodens. Oral Surg Oral Med Oral Path 27:360-362.

Smith RA, Gordon NC, DeLuchi SF. 1979. Intranasal teeth: Report of two cases and review of the literature Oral Surg Oral Med Oral Path 47:120-122.
Sykaras SN. 1975. Mesiodens in primary and permanent dentitions: Report of a case. Oral Surg Oral Med Oral Path 39:870-874.

Tay F, Pang A, Yuen S. 1984. Unerupted maxillary anterior supernumerary teeth: Report of 204 cases. ASDC J Dent Child 51:289-294.

Ubelaker DH. 1989. Human skeletal remains: Excavation, analysis, interpretation, 2nd ed. Washington DC: Taraxacum Press.

von Arx T. 1992. Anterior maxillary supernumerary teeth: A clinical and radiographic study. Aust Dent J 37:189-195.

Zhu JF, Marcushamer M, King DL, Henry RJ. 1996. Supernumerary and congenitally absent teeth: A literature review. J Clin Pediatr Dent 20:87-95.

Zmener O. 2006. Root resorption associated with an impacted mesiodens: A surgical and endodontic approach to treatment. Dent Traumatol 22:279-282.

\section{DAA Subscription}

The secretary-treasurer of the Dental Anthropology Association is Dr. Loren R. Lease of Youngstown State University.

Dr. Loren R. Lease

Department of Sociology and Anthropology

Youngstown State University

One University Plaza

Youngstown, Ohio 44555 USA

Telephone: (330) 941-1686

E-mail: lrlease@ysu.edu

Dental Anthropology now is published electronically and e-mailed to all members as a PDF. If you also want to receive a hard copy, be sure to make this clear on the membership form at the DAA website or contact Loren.

Speed communication about your membership by contacting Loren directly (other officers may not have current membership information). 